\title{
Argon Geochronology of Late Pleistocene to Holocene Westdahl Volcano, Unimak Island, Alaska
}

\author{
By Andrew T. Calvert, Richard B. Moore, and Robert G. McGimsey
}

\section{Abstract}

High-precision ${ }^{40} \mathrm{Ar} /{ }^{39} \mathrm{Ar}$ geochronology of selected lavas from Westdahl Volcano places time constraints on several key prehistoric eruptive phases of this large active volcano. A dike cutting old pyroclastic-flow and associated lahar deposits from a precursor volcano yields an age of 1,654 \pm 11 k.y., dating this precursor volcano as older than early Pleistocene. A total of 11 geographically distributed lavas with ages ranging from $47 \pm 14$ to $127 \pm 2$ k.y. date construction of the Westdahl volcanic center. Lava flows cut by an apparent caldera-rim structure yielded ages of $81 \pm 5$ and $121 \pm 8$ k.y., placing a maximum date of $81 \mathrm{ka}$ on caldera formation. Late Pleistocene and Holocene lavas fill the caldera, but most of them are obscured by the large summit icecap.

\section{Introduction}

Westdahl Volcano is a large, ice-clad shield volcano on the southwest end of Unimak Island (fig. 1), the easternmost large island of the Aleutian chain in Alaska. Historical eruptions of Westdahl Volcano have been recorded (Coats, 1950; McGimsey, 1995), and inflation has been detected by satellite radar interferometry (Dean and others, 2002; Lu and others, 2003). Our geologic mapping of the edifice in 1998-2000 established a relative chronology of the volcanic deposits. Abundant Holocene lavas drape late Pleistocene and older volcanic deposits. Here, we report on the ${ }^{40} \mathrm{Ar} /{ }^{39} \mathrm{Ar}$ geochronology of 12 Pleistocene samples that date construction of the main edifice and provide clues to the volcano's eruptive history.

\section{Geologic Context}

Unimak Island (fig. 1) contains several of the most active Aleutian volcanoes, including Shishaldin Volcano, Fisher Caldera, and Westdahl Volcano, each with substantial Holocene deposits and protracted eruptive histories (Wood and Kienle, 1990). Westdahl Volcano, which covers the southwest end of the island, is here defined to include the many flank vents outside the summit area, chiefly on the northwest, northeast, and southeast flanks (fig. 1). Three large peripheral vents aligned along a northwest-southeastward trend are included:
(1) Pogromni Volcano (elev 1,991 m), adjacent Pogromni's Sister (elev 1,219 m), and large glaciated flank vents 6 to 9 $\mathrm{km}$ north-northwest of Westdahl Peak; (2) an unnamed dacite dome (elev $401 \mathrm{~m}$ ) $5 \mathrm{~km}$ northwest of Pogromni Volcano; and (3) Promontory Hill (elev $335 \mathrm{~m}$ ), an eroded tuff cone $12 \mathrm{~km}$ southeast of Westdahl Peak.

Westdahl Volcano consists of a broad, somewhat-flattened shield built on an eroded precursor volcano. Including the peripheral vents, Westdahl deposits cover an oval $\sim 38 \mathrm{~km}$ northwest-southeast by $25 \mathrm{~km}$ northeast-southwest (fig. 1). During geologic mapping, we identified inward-facing scarps on the west and east sides of the summit area, suggesting that an $\sim 9$-km-diameter, nearly circular collapse caldera may have formed after the shield was built and that the caldera has subsequently been filled by numerous late Pleistocene to Holocene lavas. Two mapped lavas appear to project significantly above the present summit, suggesting that the volcano was steeper and considerably taller when they were emplaced. These lavas appear to have been truncated by a caldera-rim structure, and the ages described below should provide a maximum date for caldera collapse. Two Holocene cones, Westdahl Peak (elev 1,560 m) and Faris Peak (elev 1,660 m), rise above the summit ice, but no pre-Holocene, postcaldera lavas have been identified. Basaltic andesite and andesite pyroclasticflow deposits that overlie Scotch Cap lavas on the southwest Pacific coast were leading candidates for a caldera-forming eruption, but their limited exposure makes this relation difficult to prove.

Westdahl lavas are composed primarily of basalt and basaltic andesite, with lesser andesite and minor dacite. Limited geochemistry (Neal and Swanson, 1983; Myers, 1994; Miller and others, 1998) suggests that the Westdahl lavas are richer in alkalis than many other Aleutian arc rocks, ranging from 46 to 62 weight percent in $\mathrm{SiO}_{2}$ content and plotting within the tholeiitic field of Miyashiro (1974). One K-Ar age of 180 k.y. cited by Wood and Kienle (1990) was not reported by Neal and Swanson (1983).

\section{Analytical Techniques}

Samples for geochronology were selected to provide geographic coverage around the volcano and age constraints on Pleistocene volcano growth or collapse and on the older 
deposits upon which Westdahl Volcano was built. Candidate samples were scrutinized petrographically, and samples were chosen by using three basic criteria: (1) freshness, to minimize contaminant argon; (2) crystallinity, to ensure that samples retained radiogenic argon since formation; and (3) coarse groundmass textures, to minimize complications during irradiation. All analyzed samples contained no visible alteration minerals and $<3$ volume percent glass and had coarse groundmass textures (groundmass feldspar grain size, $>10 \mu \mathrm{m}$ diameter). Rocks were crushed in a roller mill, ultrasonicated in deionized water, sized appropriately $(425-500 \mu \mathrm{m}$ diameter for most samples, 250-350 $\mu \mathrm{m}$ diameter for crystal-rich lavas), stripped of phenocrysts magnetically, and handpicked for purity. Sample mass ranged from 130 to $150 \mathrm{mg}$.

Separates were wrapped in pure copper foil, encapsulated in quartz tubing along with Taylor Creek sanidine monitor minerals, shielded with a single wrap of 0.58 -mm-thick cadmium foil, loaded into an aluminum irradiation tube, and irra-

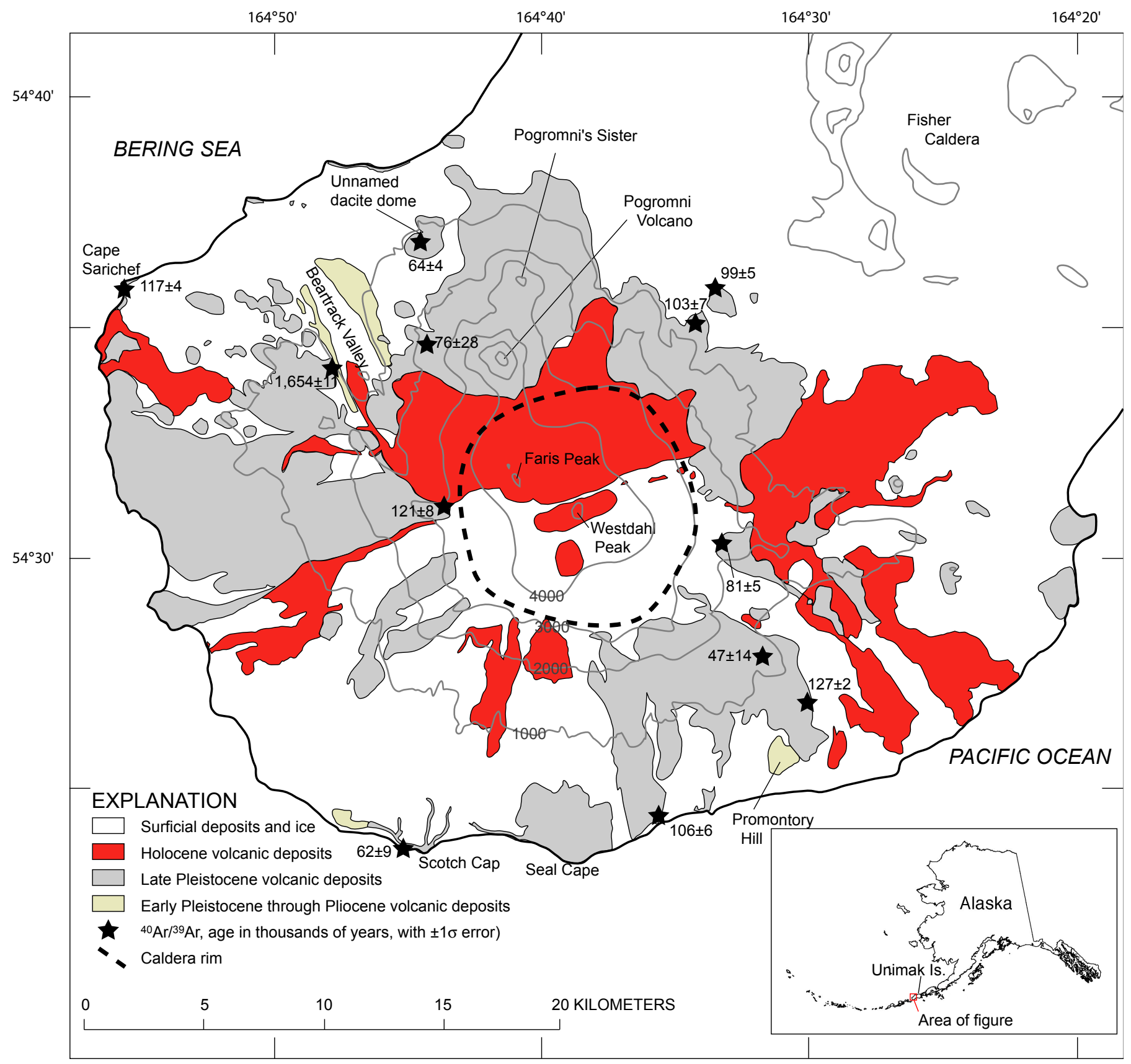

Figure 1. Simplified geologic map of Westdahl Volcano, western Unimak Island, Alaska, showing locations of geochronology samples (stars) selected from pre-Holocene units (gray and beige areas). Caldera rim is not exposed but is inferred from topography. Contour interval, $1,000 \mathrm{ft}$. 
diated for 2 hours in the central thimble of the TRIGA reactor at the U.S. Geological Survey (USGS) laboratory in Denver, Colo. The base of the irradiation tube was positioned $2 \mathrm{~cm}$ above the reactor centerline, and the tube was rotated continuously during irradiation. Taylor Creek sanidine (TCR-2, 27.87 m.y.) is a Menlo Park, Calif., internal standard calibrated to SB-3 biotite (Lanphere and Dalrymple, 2000).

The USGS Menlo Park, Calif., ${ }^{40} \mathrm{Ar} /{ }^{39} \mathrm{Ar}$ facility is equipped with both an argon ion laser and a Staudacher-type resistance furnace attached to an all-metal extraction line. An early version of the extraction line and spectrometer was described by Dalrymple (1989), and pertinent modifications are outlined below. Six sanidine fractions from each of four monitor packets were fused with the laser, extracted gas was cleaned with two SAES AP-10 getters, and remaining noble gases were analyzed on a MAP 216 mass spectrometer fitted with a Baur-Signer source and a Johnston MM1 multiplier run at $\sim 2 \mathrm{kV}$. The neutron-flux parameter $J$ for each sample packet was calculated from a quadratic fit to monitor data from four points along the irradiation tube.

Sample packets were heated stepwise in the resistance furnace for 8 minutes at each temperature listed in figure 2; temperatures were controlled to within $\pm 1^{\circ} \mathrm{C}$ with an optical infrared sensor. Extracted gas was cleaned for 12 minutes with the two SAES AP-10 getters, and the resulting gas was analyzed on the MAP 216 mass spectrometer. Isotopic intensities were regressed back to inlet time. Each mass intensity was corrected for mass-spectrometer baseline, and extraction-line backgrounds were run every three to five heating steps. Hot blanks were run but not corrected from these samples because the blank was small and atmospheric in composition. Mass discrimination was measured by using atmospheric argon and was equivalent to ${ }^{40} \mathrm{Ar} /{ }^{36} \mathrm{Ar}=291.61$ for these samples. Correction factors for argon isotopes produced from $\mathrm{K}$ and $\mathrm{Ca}$ during irradiation were determined by using coirradiated synthetic $\mathrm{K}$ glass and $\mathrm{CaF}_{2}$.

Sample ratios and ages were calculated by using inhouse software. Although we strove to choose perfect samples, nearly all the results reported on here are slightly complex. To illustrate our results, we show two types of graphs (fig. 2): (1) age-spectrum diagrams with stacked $\mathrm{K} / \mathrm{Ca}$ ratio and radiogenic-yield plots, and (2) isotope-correlation (isochron) diagrams. The age-spectrum diagrams plot the apparent age and $\pm 1 \sigma$ error of each gas fraction versus the cumulative percent of ${ }^{39} \mathrm{Ar}$ released. Apparent ages were calculated by assuming that the nonradiogenic argon released at each heating step has the modern-day atmospheric ratio, presently defined as ${ }^{40} \mathrm{Ar} /{ }^{36} \mathrm{Ar}=295.5$, but normalized to atmosphere by the mass-discrimination measurement described above. Most results yielded plateau ages, here defined as at least 50 percent of ${ }^{39} \mathrm{Ar}$ released within $\pm 2 \sigma$ error on contiguous heating steps; these results generally have correspondingly good isochron fits. For younger volcanic rocks, we employed a standard isochron diagram that plots ${ }^{39} \mathrm{Ar} /{ }^{36} \mathrm{Ar}$ against ${ }^{40} \mathrm{Ar} /{ }^{36} \mathrm{Ar}$; inverse isochron analysis $\left({ }^{39} \mathrm{Ar} /{ }^{40} \mathrm{Ar}\right.$ versus ${ }^{36} \mathrm{Ar} /{ }^{40} \mathrm{Ar}$ ratio) yielded indistinguishable results but illustrated the results less clearly. The weighted-regression line of York (1969) was fitted to the data. The $y$-axis intercept corresponds to the isotopic ratio of the trapped component, and the slope of the line is proportional to the age. A mean square of weighted deviates (MSWD) was calculated for the isochron data to estimate goodness of fit; MSWD $>>1$ indicates excess dispersion or multiple trapped components, whereas MSWD $<<1$ suggests overestimation of errors.

\section{Interpretative Techniques}

Theoretically, a pristine sample should yield identical ages throughout the stepwise-heating experiment, and a weighted mean of those ages represents the crystallization age of the lava flow. This behavior commonly holds true for potassic phases in rocks but less commonly for argon experiments on volcanic rocks (for example, Singer and Pringle, 1996). Several factors complicate the results. (1) Altered samples commonly lose radiogenic argon and (or) entrain significant amounts of atmospheric argon. Argon loss is commonly reflected by young apparent ages at low temperatures, sometimes reaching a geologically "reasonable" age. Samples with abundant atmospheric argon yield ages with unusually large errors and can suppress the ion beam such that heating steps appear discordant. (2) Fine-grained samples (groundmass feldspar grain size, $<5 \mu \mathrm{m}$ ) behave poorly with the ${ }^{40} \mathrm{Ar} /{ }^{39} \mathrm{Ar}$ technique because fast-neutron bombardment of ${ }^{39} \mathrm{~K}$ causes the resulting ${ }^{39} \mathrm{Ar}$ atom to recoil $\sim 0.1 \mu \mathrm{m}$ (Turner and Cadogan, 1974; Huneke and Smith, 1976; Foland and others, 1992). If the resulting ${ }^{39} \mathrm{Ar}$ atom comes to rest in either a more or less retentive position than the ${ }^{39} \mathrm{~K}$, it will not be extracted at the same rate as ${ }^{40} \mathrm{Ar}$ during analysis. In this situation, the ${ }^{40} \mathrm{Ar}$ and ${ }^{39} \mathrm{Ar}$ would no longer be distributed as the ${ }^{40} \mathrm{~K}$ and ${ }^{39} \mathrm{~K}$ were, and so the resulting isotopic ratios may not be correlated. Typical argon-release patterns from rocks plagued with recoil problems include old apparent ages early (10-30 percent of ${ }^{39} \mathrm{Ar}$ released) in the experiment, stepping down to a flat portion (20-80 percent of ${ }^{39} \mathrm{Ar}$ released), followed by young apparent ages later (70-100 percent of ${ }^{39} \mathrm{Ar}$ released). These flat portions, which are interpreted as crystallization ages, generally match conventional K-Ar ages. A few samples yield no flat segment, and so age interpretation is impossible. Total-gas ages, based on the sum of all gas fractions released, are analogous to a conventional $\mathrm{K}-\mathrm{Ar}$ age, although they also reflect recoil issues. (3) In most samples, the final 10-20 percent of ${ }^{39} \mathrm{Ar}$ released yields old apparent ages; these steps have low $\mathrm{K} / \mathrm{Ca}$ ratios and are believed to reflect excess (magmatic?) argon from nonpotassic phases, such as pyroxene and olivine. This excess argon can be either restricted to high-temperature steps or released throughout a stepwise-heating experiment. Excess argon is most easily recognized as high ${ }^{40} \mathrm{Ar} /{ }^{36} \mathrm{Ar}$ ratios on an isochron plot.

Isochron diagrams plot the measured isotopic ratios without the atmospheric-argon correction. Plots of undisturbed samples should yield linear arrays with slopes proportional to age and ${ }^{40} \mathrm{Ar} /{ }^{36} \mathrm{Ar}$ intercepts indicating the trapped, nonradiogenic component, for most samples within error of the atmospheric-argon ratio $\left({ }^{40} \mathrm{Ar} /{ }^{36} \mathrm{Ar}=295.5\right)$. Because many rocks are somewhat complex, they can contain multiple argon reservoirs and the isochron results may be complicated. 

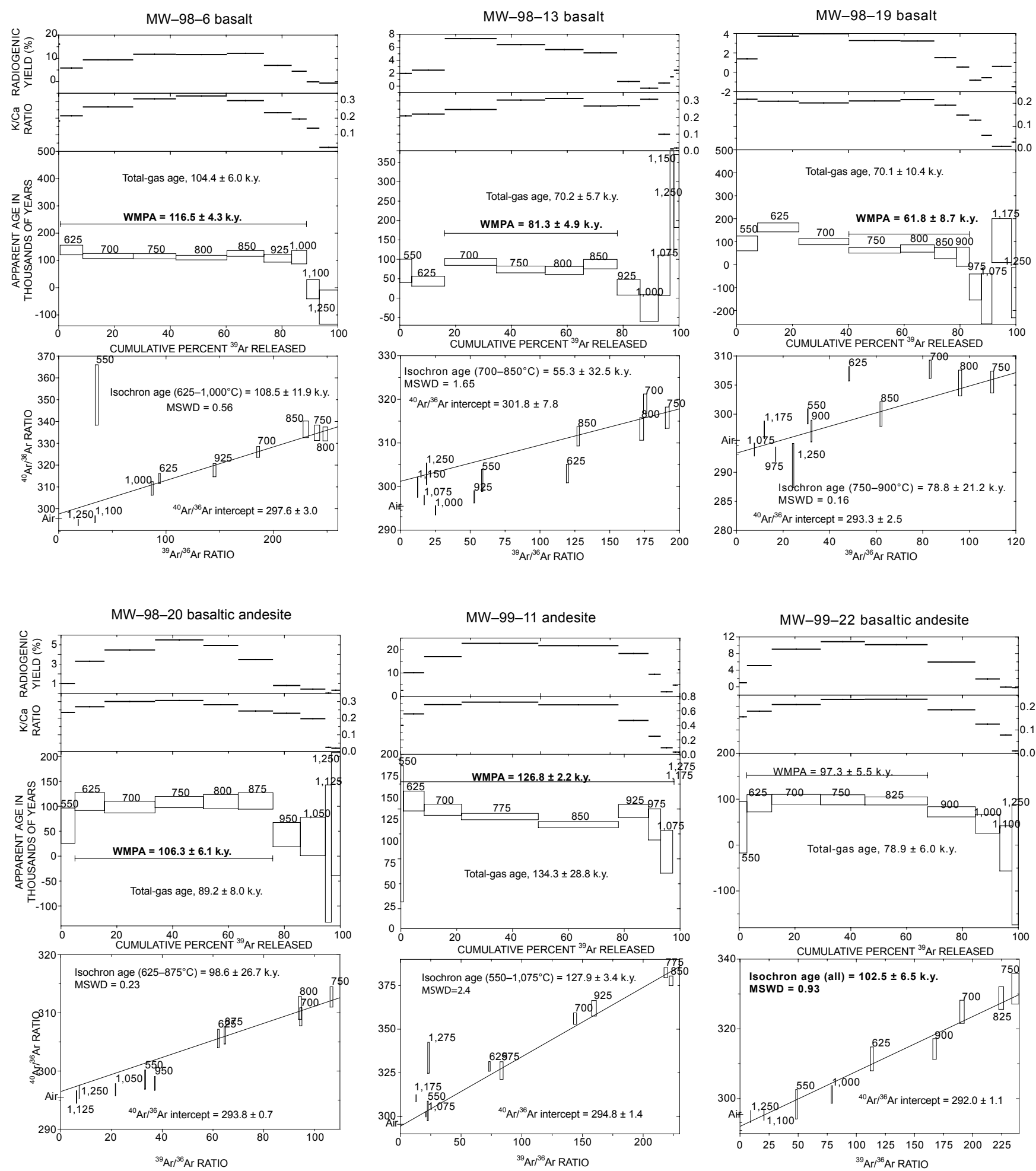

Figure 2. ${ }^{40} \mathrm{Ar} /{ }^{39} \mathrm{Ar}$ age spectra, $\mathrm{K} / \mathrm{Ca}$ ratios, radiogenic yields, and isochron plots for Westdahl volcanic rocks. Apparent ages, isotopicratio boxes, interpreted ages, and ${ }^{40} \mathrm{Ar} /{ }^{36} \mathrm{Ar}$ ratios are all $\pm 1 \sigma$. Brackets on age spectra show heating steps used to calculate weightedmean plateau age (WMPA). Temperature labels in degrees Celsius. Interpreted ages in bold. 

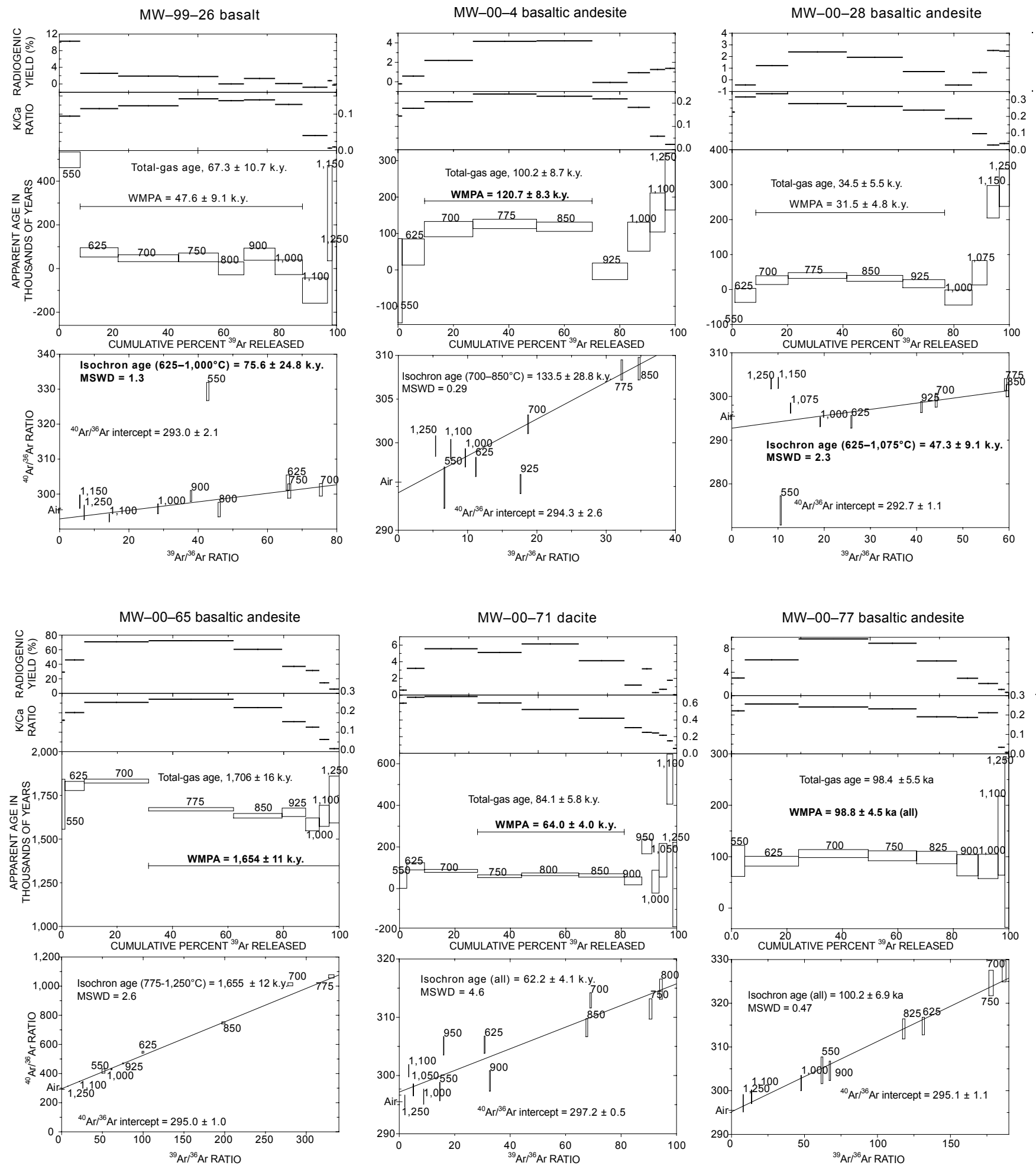

Figure 2.-Continued 
Deviations from linear arrays can represent multiple trapped components, alteration of components, or irradiation effects. Common complexities in volcanic rocks include (1) high ${ }^{40} \mathrm{Ar}{ }^{36} \mathrm{Ar}$ ratios at high temperatures, inferred to be excess argon from low-K phases; and (2) ${ }^{39}$ Ar-recoil problems, resulting in decreased ${ }^{39} \mathrm{Ar} /{ }^{36} \mathrm{Ar}$ ratios at low temperatures and increased ${ }^{39} \mathrm{Ar} /{ }^{36} \mathrm{Ar}$ ratios at high temperatures. Isochron ages are favored when the $y$-axis intercept differs statistically from atmosphere and the MSWD is within the critical range defined by Mahon (1996). Analytical uncertainties for isochron results outside the critical range are multiplied by the square root of the resulting MSWD (for example, Ludwig, 1999) to incorporate a measure of the increased scatter.

\section{${ }^{40} \mathrm{Ar} /{ }^{39} \mathrm{Ar}$ Geochronology of Westdahl Volcano}

Sample results are presented from oldest to youngest, in the order discussed subsequently. Age-spectrum diagrams, stacked $\mathrm{K} / \mathrm{Ca}$ ratios and radiogenic yields, and isochron results are illustrated in figure 2 and listed in tables 1 and 2.

Sample MW-00-65: Basaltic andesite dike (52.9 weight percent $\mathrm{SiO}_{2}$ ) cutting old pyroclastic deposits, northwest sector.-Apparent ages for sample MW-00-65 range from 1,630 to $1,830 \mathrm{k}$.y. and display typical ${ }^{39} \mathrm{Ar}$-recoil patterns, with old apparent ages stepping downward throughout the experiment. Using the $775-1,250^{\circ} \mathrm{C}$ heating steps yields a plateau age of $1,654 \pm 11$ k.y. and an isochron age of 1,655 \pm 19 k.y. An old totalgas age is interpreted as net loss of ${ }^{39} \mathrm{Ar}$ by recoil early in the experiment. Our preferred age is the 1,654 $\pm 11-k . y$. plateau age.

Sample MW-99-11: Andesite flow (58.8 weight percent $\mathrm{SiO}_{2}$ ), southeast sector.-Sample MW-99-11, from a stratigraphically deep andesite flow, yielded a plateau age of $127 \pm 2$ k.y. All but the last two heating steps yielded apparent ages within error, and most heating steps had relatively high radiogenic yields (10-20 percent of ${ }^{39} \mathrm{Ar}$ released). The isochron age for these heating steps is identical, with a slightly elevated MSWD value of 2.4. The total-gas age of $134 \pm 29$ k.y. reflects modest excess argon in the final two heating steps. Our preferred age is the $127 \pm 2-k . y$. plateau age.

Sample MW-00-4: Basaltic andesite flow (53.1 weight percent $\mathrm{SiO}_{2}$ ), west caldera rim.- Sample MW-00-4 is from one of two flows that appear to be truncated by a caldera rim, providing an upper bound on the inferred date of caldera formation. Argon systematics are somewhat disturbed, but a plateau age of $121 \pm 8 \mathrm{k} . \mathrm{y}$. is defined. The $925^{\circ} \mathrm{C}$ heating step yielded an apparent age near $0 \mathrm{k} . \mathrm{y}$., possibly owing to degassing of a fluid inclusion or another nonradiogenic reservoir. Disregarding that step, release of all gas within $\pm 2 \sigma$ error would yield a plateau age of $116 \pm 8 \mathrm{k}$.y. Isochron ages, which range from $117 \pm 31$ k.y. (all heating steps) to $134 \pm 29$ k.y. ( $700-850^{\circ} \mathrm{C}$ heating steps), support the plateau age. The total-gas age of $100 \pm 9$ k.y. is probably too young, owing to the discordant $925^{\circ} \mathrm{C}$ heating step. Our preferred age is the $121 \pm 8$-k.y. plateau age.
Sample MW-98-6: Lowest exposed basalt flow (51.1 weight percent $\mathrm{SiO}_{2}$ ), Cape Sarichef, northwest sector.-Sample MW-98-6 yielded a flat plateau-age spectrum comprising 88 percent of ${ }^{39} \mathrm{Ar}$ released, with a plateau age of $117 \pm 4$ k.y. Low- and high-temperature heating steps are slightly discordant. The isochron suggests a slightly high $y$-axis intercept, but the $109 \pm 12$-k.y. age is within error of the plateau age. Our preferred age is the 117 4-k.y. plateau age.

Sample MW-98-20: Lowest exposed basaltic andesite flow (53.0 weight percent $\mathrm{SiO}_{2}$ ), Seal Cape, southeast sector- - Sample MW-98-20 yielded a plateau age of 106 \pm 6 k.y. and supporting isochron age of $99 \pm 27$ k.y. The slightly younger total-gas age reflects low apparent ages at high temperature, probably owing to modest ${ }^{39} \mathrm{Ar}$ recoil. Our preferred age is the $106 \pm 6-\mathrm{k} . \mathrm{y}$. plateau age.

Samples $M W-00-77$ and $M W-99-22:$ Basaltic andesites (52.3 weight percent $\mathrm{SiO}_{2}$ ), northeast sector.-Samples MW-00-77 and MW-99-22 behaved similarly, have similar chemistry and rock textures, and are likely from the same package of flows. Sample MW-00-77 yielded a perfect plateau age of $99 \pm 5$ k.y., with a concordant isochron. Sample MW-99-22 yielded a hump-shaped age spectrum, with a $97 \pm 6-k . y$. plateau age and an isochron of $103 \pm 7$ k.y.; the isochron age is preferred because its $y$-axis intercept differs from the atmospheric ${ }^{40} \mathrm{Ar} /{ }^{36} \mathrm{Ar}$ ratio outside analytical error. Our preferred age for sample MW-00-77 is the 99 \pm 5 -k.y. plateau age, and for sample MW-99-22 the 103 \pm -k.y. isochron age.

Sample $\mathrm{MW}-98-13$ : Basalt (50.4 weight percent $\mathrm{SiO}_{2}$ ), east caldera rim.- Sample MW-98-13, from a basalt flow that also appears to be truncated by the caldera rim, provides an upper bound on the date of caldera formation on the east flank of Westdahl Volcano. The sample yielded a plateau age of $81 \pm 5$ k.y. Early and late heating steps had younger ages and poor radiogenic yields. The isochron age of $55 \pm 33$ k.y. appears to be younger but has large errors due to scatter and the limited range in ${ }^{39} \mathrm{Ar} /{ }^{36} \mathrm{Ar}$ ratio for plateau $\left(700-850^{\circ} \mathrm{C}\right)$ heating steps. An isochron array including all heating steps yielded an age of $82 \pm 6 \mathrm{k}$.y. with a high MSWD of 3.59. Our preferred age is the $81 \pm 5$-k.y. plateau age.

Sample MW-00-71: Dacite dome (63.3 weight percent $\left.\mathrm{SiO}_{2}\right)$, northwest sector.-Sample MW-00-71 yielded a recoil-complicated age spectrum, with a plateau age of $64 \pm 4$ k.y. on intermediate heating steps comprising 53 percent of ${ }^{39} \mathrm{Ar}$ released. An isochron age including all heating steps is indistinguishable at $62 \pm 4 \mathrm{k}$.y. but has an elevated MSWD of 4.6. Our preferred age is the 64 $\pm 4-\mathrm{k} . \mathrm{y}$. plateau age.

Sample MW-98-19: Basal basalt flow (50.2 weight percent $\mathrm{SiO}_{2}$ ), Scotch Cap.-Sample MW-98-19, from a basalt flow underlying thick basaltic andesite and andesite pyroclastic flows, yielded a plateau age of $62 \pm 9$ k.y., likely complicated by ${ }^{39} \mathrm{Ar}$ recoil. The plateau is short, with only 43 percent of ${ }^{39} \mathrm{Ar}$ released (outside our defined threshold of $>50$ percent ${ }^{39} \mathrm{Ar}$ released), and the isochron age of $79 \pm 21 \mathrm{k} . \mathrm{y}$. for those heating steps is concordant but has a large uncertainty. Our preferred age is the $62 \pm 9-\mathrm{k}$.y. plateau age. 
Sample MW-99-26: Basalt (47.4 weight percent $\mathrm{SiO}_{2}$ ) from Pogromni Volcano.-Sample MW-99-11 is a relatively old lava from deep within Pogromni Volcano (fig. 1). The plateau-age spectrum shows decreasing ages but within error at $48 \pm 9$ k.y. A good isochron fit yielded an older age of $76 \pm 25$ k.y. with a lower-than-atmospheric $y$-axis intercept. Because the $y$-axis intercept is not within error of atmosphere, our preferred age is the 76 $\pm 25-\mathrm{k} . \mathrm{y}$. isochron age.

Sample MW-00-28: Basaltic andesite (53.1 weight percent $\mathrm{SiO}_{2}$ ), young flow in thick shield-building sequence, southeast sector.-Sample MW-00-28 yielded a broadly hump shaped age spectrum, with most heating steps yielding < 50-k.y. ages and an overall plateau age of $32 \pm 5$ k.y. The isochron age including 91 percent of ${ }^{39} \mathrm{Ar}$ released yielded an age of $47 \pm 14$ k.y. with a lower-than-atmospheric $y$-axis intercept. No vent is exposed for this lava, and so it is difficult to know to which phase of

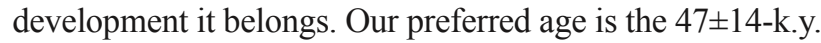
isochron age.

\section{Construction of the Westdahl Volcanic Center}

Geologic mapping of the Westdahl volcanic center (fig. 1) identified four phases in its construction that we can now assign to specific times or intervals: (1) Pliocene through early Pleistocene pre-Westdahl volcanism, (2) late Pleistocene shield or stratovolcano growth, (3) caldera collapse, and (4) later infilling of the caldera.

\section{Pliocene Through Early Pleistocene PreWestdahl Volcanism}

Pyroclastic-flow and associated lahar deposits exposed in the walls of Beartrack Valley northwest of Westdahl Volcano

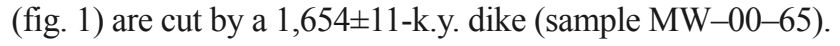
Other possibly related deposits that are undated include a steeply dipping, eroded vent complex at Scotch Cap (southwest of Westdahl Volcano) and tuff, spatter deposits, lava flows, and dikes of Promontory Hill (southeast of Westdahl Volcano). These deposits lie along the same northwest-southeastward trend as Pogromni Volcano and a dacite dome northwest of Pogromni Volcano, and so they may be associated with the modern volcanic system.

\section{Late Pleistocene Shield or Stratovolcano Growth}

The present mesalike topographic profile of Westdahl Volcano (fig. 1) suggests that it was a large shield or stratovolcano early in its history but later lost its summit. The older edifice is built of lavas and pyroclastic rocks. Samples of basalt and andesite flows collected from the deepest accessible parts of the volcano, exposed in canyons on its flanks, are as much as 127 k.y. old; samples at higher stratigraphic levels across the map area range in age from $47 \pm 14$ to $117 \pm 4$ k.y. Two units cut by the inward-facing structure interpreted to be a caldera rim yielded ages of $81 \pm 5$ and $121 \pm 8$ k.y.

\section{Late Pleistocene Caldera Collapse}

Our geologic mapping suggests that a 9-km-diameter caldera occupies the broad summit area of Westdahl Volcano (fig. 1), now filled with younger lavas. Two of the dated lavas that are truncated by the caldera rim constrain the calderaforming event(s) to post- $81 \pm 5$ and $121 \pm 8$ k.y. No pyroclastic-flow deposit has been tied to a caldera-forming eruption at Westdahl Volcano, although several pyroclastic flows are exposed. One thick candidate pyroclastic-flow deposit at the coast near Scotch Cap overlies the 62 \pm 9 -k.y. Scotch Cap basalt flow. The age of Pogromni Volcano may constrain the date of a caldera-forming eruption. If the Pogromni deposits drape the caldera rim, the $76 \pm 28$-k.y.-old flow dated from deep in the edifice could provide a minimum date for caldera formation. The dacite dome northwest of Pogromni Volcano dated at $64 \pm 4$ k.y. and the 62 \pm 9 -k.y.-old Scotch Cap flow suggests that the Westdahl volcanic center may have been especially active during the period $80-60 \mathrm{ka}$.

\section{Later Infilling of the Caldera}

Many late Pleistocene and Holocene lava flows fill the caldera and drape older lavas. No samples that constrain the beginning of infilling were dated; however, many of the postcaldera lavas are significantly glaciated, suggesting emplacement before the latest glacial maximum (LGM).

\section{Conclusions}

Westdahl Volcano is built on the remnants of an eroded, early Pleistocene or older volcano. During the period $\sim 130-80$ $\mathrm{ka}$, the volcano built a $>25-\mathrm{km}$-diameter shield or stratovolcano, primarily basaltic to andesitic in composition. Sometime after $81 \mathrm{ka}$ and before the LGM, a 9-km-diameter caldera formed at the summit; no deposits associated with this event have been identified. Late Pleistocene and Holocene lava flows have filled the caldera and flowed down adjacent valleys. Most of the summit caldera is ice covered, and historical basaltic eruptions continue to rebuild the edifice.

\section{Acknowledgments}

This research was supported by the Alaska Volcano Observatory and the USGS Volcano Hazards Program. Andy Ouimette crushed and separated the rocks. James Saburomaru packaged and loaded samples for irradiation and handled them upon their return. Tim Debey and staff irradiated samples at the USGS TRIGA reactor facility in Denver, Colo. Charlie Bacon and Bob Fleck provided helpful reviews of the manuscript, and editors John Galloway and George Havach improved its readability. 


\section{References Cited}

Coats, R.R., 1950, Volcanic activity in the Aleutian Arc: U.S. Geological Survey Bulletin 974-B, p. 35-49.

Dalrymple, G.B., 1989, The GLM continuous laser system for ${ }^{40} \mathrm{Ar} /{ }^{39} \mathrm{Ar}$ dating; description and performance characteristics, in Shanks, W.C., III, and Criss, R.E., eds., New frontiers in stable isotopic research; laser probes, ion probes, and small-sample analysis: U.S. Geological Survey Bulletin 1890, p. 89-96.

Dean, K.G., Engle, Kevin, Groves, J.R., Dehn, Jonathan, and Partington, Kim, 2002, Analysis of surface processes using SAR data; Westdahl Volcano, Alaska: International Journal of Remote Sensing, v. 23, no. 21, p. 4529-4550.

Foland, K.A., Hubacker, F.A., and Arehart, G.B., 1992, ${ }^{40} \mathrm{Ar} /{ }^{39} \mathrm{Ar}$ dating of very fine-grained samples - an encapsulated-vial procedure to overcome the problem of ${ }^{39} \mathrm{Ar}$ recoil loss: Chemical Geology, v. 102, no. 1-4, p. 269-276.

Huneke, J.C., and Smith, S.P., 1976, The realities of recoil; ${ }^{39} \mathrm{Ar}$ recoil out of small grains and anomalous age patterns in ${ }^{39} \mathrm{Ar}-{ }^{40} \mathrm{Ar}$ dating: Lunar Science Conference, 7 th, Houston, Tex., 1976, Proceedings, p. 1987-2008.

Lanphere, M.A., and Dalrymple, G.B., 2000, First-principles calibration of ${ }^{38} \mathrm{Ar}$ tracers; implications for the ages of ${ }^{40} \mathrm{Ar} /{ }^{39} \mathrm{Ar}$ fluence monitors: U.S. Geological Survey Professional Paper 1621, $10 \mathrm{p}$.

Lu, Zhong, Masterlark, Timothy, Dzurisin, Daniel, Rykhus, Russell and Wicks, Charles, 2003, Magma supply dynamics at Westdahl Volcano, Alaska, modeled from satellite radar interferometry: Journal of Geophysical Research, v. 108, no. B7, DOI 10.1029/2002JB002311, 17 p.

Ludwig, K.R., 1999. User's manual for Isoplot/Ex version 2, a geochronological toolkit for Microsoft Excel: Berkeley, Calif., Berkeley Geochronology Center Special Publication 1a, $47 \mathrm{p}$.
Mahon, K., 1996, The New "York" regression: application of an improved statistical method to geochemistry: International Geology Review, v. 38, no. 4, p. 293-303.

McGimsey, R.G., 1995, Report on Westdahl Volcano: Bulletin of Volcanic Eruptions, 1992, v. 32, p. 92-94.

Miller, T.P., McGimsey, R.G., Richter, D.H., Riehle, J.R., Nye, C.J., Yount, M.E., and Dumoulin, J.A., 1998, Catalog of the historically active volcanoes of Alaska: U.S. Geological Survey Open-File Report 98-582, 104 p.

Miyashiro, Akiho, 1974, Volcanic rock series in island arcs and active continental margins: American Journal of Science, v. 274, no. 4, p. 321-355.

Myers, J.D., 1994, The geology, geochemistry and petrology of the recent magmatic phase of the central and western Aleutian Arc: URL http://www.avo.alaska.edu/.

Neal, R.J., and Swanson, S.E., 1983, Petrology and geochemistry of Westdahl and Pogromni volcanoes, Unimak Island, Alaska [abs.]: Eos (American Geophysical Union Transactions), v. 64 , no. 45 , p. 893 .

Singer, B.S., and Pringle, M.S., 1996, Age and duration of the Matuyama-Brunhes geomagnetic polarity reversal from ${ }^{40} \mathrm{Ar} /{ }^{39} \mathrm{Ar}$ incremental heating analyses of lavas: Earth and Planetary Science Letters, v. 139, no. 1-2, p. 47-61.

Turner, Grenville, and Cadogan, P.H., 1974, Possible effects of ${ }^{39} \mathrm{Ar}$ recoil in ${ }^{40} \mathrm{Ar} /{ }^{39} \mathrm{Ar}$ dating: Lunar Science Conference, 5th, Houston, Tex., 1974, Proceedings, p. 1601-1615.

Wood, C.A., and Kienle, Juergen, eds., 1990, Volcanoes of North America; United States and Canada: New York, Cambridge University Press, 354 p.

York, Derek, 1969, Least squares fitting of a straight line with correlated errors: Earth and Planetary Science Letters, v. 5, no. 5, p. 320-324. 
Tables 1, 2 
Table 1. Summary of ${ }^{40} \mathrm{Ar} /{ }^{39} \mathrm{Ar}$ results for selected samples of Westdahl volcanic rocks.

[All ages in thousands of years with $\pm 1 \sigma$ analytical uncertainties. Interpreted ages (in bold) are plateau ages, except where age spectra are disturbed or ${ }^{40} \mathrm{Ar}{ }^{36} \mathrm{Ar} \mathrm{r}_{\mathrm{i}}$ ratio on isochron plot is outside $\pm 2 \sigma$ error of present-day atmosphere (295.5). For isochron ages beyond the 95-percent-confidence limits of Mahon (1996) (in italics), the error is multiplied by the square root of the mean square of weighted deviates (MSWD) (Ludwig, 1999). Ages relative to the Taylor Creek Rhyolite sanidine (TCR-2) at 27.87 m.y. calibrated to SB-3 biotite (Lanphere and Dalrymple, 2000)]

\begin{tabular}{|c|c|c|c|c|c|c|c|c|}
\hline Sample & Description & Total gas age & Plateau age & $\begin{array}{l}\text { Steps used } \\
\text { (percent of } \\
{ }^{39} \mathrm{Ar} \text { released) }\end{array}$ & Isochron age & $\begin{array}{l}\text { Steps used } \\
\text { (percent of } \\
{ }^{39} \mathrm{Ar} \text { released) }\end{array}$ & $\begin{array}{l}{ }^{40} \mathrm{Ar} /{ }^{36} \mathrm{Ar} \\
\text { intercept }\end{array}$ & MSWD \\
\hline MW-98-6 & Basal basalt flow, Cape Sarichef & $104.4 \pm 6.0$ & $116.5 \pm 4.3$ & $625-1,000(88.3)$ & $108.5 \pm 11.9$ & $625-1,000(88.3)$ & $297.6 \pm 3.0$ & 0.56 \\
\hline MW-98-13 & High standing precaldera basalt & $70.2 \pm 5.7$ & $81.3 \pm 4.9$ & $700-850(61.7)$ & $55.3 \pm 41.7$ & $700-850(61.7)$ & $301.8 \pm 7.8$ & 1.65 \\
\hline MW-98-19 & Basal basalt flow, Scotch Cap & $70.1 \pm 10.4$ & $61.8 \pm 8.7$ & $750-900(43.1)$ & $78.8 \pm 21.3$ & $750-900(43.1)$ & $293.3 \pm 2.5$ & 0.16 \\
\hline MW-98-20 & Basal basaltic andesite flow, Seal Cape & $89.2 \pm 8.0$ & $106.3 \pm 6.1$ & $625-875(70.9)$ & $98.6 \pm 26.8$ & $625-875(70.9)$ & $296.5 \pm 3.4$ & 0.23 \\
\hline MW-98-49 & Top basalt flow in small flank vent & $-192.2 \pm 23.6$ & $-150.4 \pm 23.7$ & $625-850(77.4)$ & $22.9 \pm 98.4$ & $\begin{array}{l}550-725, \\
900-1,250(61)\end{array}$ & $292.0 \pm 1.3$ & 1.60 \\
\hline MW-99-11 & Old andesite flow & $134.3 \pm 28.8$ & $126.8 \pm 2.2$ & $550-1,075(97)$ & $127.9 \pm 8.2$ & $550-1075(97)$ & $294.8 \pm 1.4$ & 2.40 \\
\hline MW-99-22 & Basaltic andesite in canyon bottom & $78.9 \pm 6.0$ & $97.3 \pm 5.5$ & $625-825(64.7)$ & $102.5 \pm 6.5$ & All & $292.0 \pm 1.1$ & 0.93 \\
\hline MW-99-26 & Old Pogromni basalt & $67.3 \pm 10.7$ & $47.6 \pm 9.1$ & $625-1,000(80.2)$ & $75.6 \pm 28.3$ & $625-1000(80)$ & $293.0 \pm 2.1$ & 1.30 \\
\hline MW-00-4 & Precaldera basaltic andesite & $100.2 \pm 8.7$ & $120.7 \pm 8.3$ & $700-850(60.6)$ & $133.5 \pm 28.9$ & $700-850(60.6)$ & $294.3 \pm 2.6$ & 0.29 \\
\hline MW-00-28 & $\begin{array}{l}\text { Youngest basaltic andesite in thick cone- } \\
\text { building sequence. }\end{array}$ & $34.5 \pm 5.5$ & $31.5 \pm 4.8$ & $700-925(68.2)$ & $47.3 \pm 13.8$ & $625-1,075(91)$ & $292.7 \pm 1.1$ & 2.30 \\
\hline MW-00-65 & $\begin{array}{l}\text { Basaltic andesite dike cutting old pyro- } \\
\text { clastic flows. }\end{array}$ & $1,706 \pm 16$ & $1,654 \pm 11$ & $775-1,250(68.7)$ & $1,656 \pm 31$ & $775-1,250(68.7)$ & $295.0 \pm 1.0$ & 2.60 \\
\hline MW-00-71 & Dacite dome & $84.1 \pm 5.8$ & $64.1 \pm 4.0$ & $750-850(53)$ & $62.2 \pm 18.9$ & All & $297.2 \pm 0.5$ & 4.60 \\
\hline MW-00-77 & Outlying basaltic andesite flow & $98.4 \pm 5.5$ & $98.8 \pm 4.5$ & All & $100.2 \pm 6.1$ & All & $295.1 \pm 1.1$ & 0.47 \\
\hline
\end{tabular}


Table 2. Geochronologic analyses of selected samples of Westdahl volcanic rocks.

[Measured ratios are corrected for blanks, backgrounds, and radioactive decay. Reactor-produced corrections: ${ }^{40} \mathrm{Ar}^{39} \mathrm{Ar}_{\mathrm{K}}=0.000 \pm 0.004,{ }^{39} \mathrm{Ar}^{37} \mathrm{Ar}_{\mathrm{Ca}}=0.000706 \pm 0.000051$, and $\left.{ }^{36} \mathrm{Ar}^{37} \mathrm{Ar}_{\mathrm{Ca}}=0.000281 \pm 0.000009\right]$

\begin{tabular}{|c|c|c|c|c|c|c|c|c|}
\hline Step $\left({ }^{\circ} \mathrm{C}\right)$ & Age (k.y.) & K/Ca ratio & $\begin{array}{c}\text { Radiogenic }{ }^{40} \mathrm{Ar} \\
\text { (pct) }\end{array}$ & $\begin{array}{c}\text { Radiogenic }{ }^{40} \mathrm{Ar} \\
\left(10^{-15} \mathrm{~mol}\right)\end{array}$ & $\Sigma^{39} \mathrm{Ar}$ & ${ }^{40} \mathrm{Ar} /{ }^{39} \mathrm{Ar}$ ratio & ${ }^{37} \mathrm{Ar} /{ }^{39} \mathrm{Ar}$ ratio & ${ }^{36} \mathrm{Ar} /{ }^{39} \mathrm{Ar}$ ratio \\
\hline \multicolumn{9}{|c|}{ Sample MW-98-6 } \\
\hline 550 & $1,130.35 \pm 229.13$ & 0.183 & 16.1 & 1.32 & 0.01 & 9.91648 & 2.66587 & 0.0289084 \\
\hline 625 & $138.33 \pm 17.71$ & 0.214 & 5.9 & 2.49 & 0.09 & 3.33410 & 2.28596 & 0.0112651 \\
\hline 700 & $116.27 \pm 9.13$ & 0.267 & 9.4 & 4.65 & 0.27 & 1.75253 & 1.82985 & 0.0058891 \\
\hline 750 & $115.45 \pm 9.47$ & 0.316 & 11.7 & 3.92 & 0.42 & 1.38964 & 1.54719 & 0.0045851 \\
\hline 800 & $110.38 \pm 8.37$ & 0.334 & 11.6 & 4.47 & 0.60 & 1.34470 & 1.46663 & 0.0044345 \\
\hline 850 & $125.59 \pm 10.57$ & 0.306 & 12.2 & 3.70 & 0.74 & 1.46014 & 1.60139 & 0.0047903 \\
\hline 925 & $107.92 \pm 14.14$ & 0.233 & 7.0 & 2.38 & 0.83 & 2.18510 & 2.10371 & 0.0074693 \\
\hline 1,000 & $112.02 \pm 24.66$ & 0.195 & 4.5 & 1.34 & 0.89 & 3.54187 & 2.50778 & 0.0121547 \\
\hline 1,100 & $-5.61 \pm 35.15$ & 0.140 & -0.1 & -0.06 & 0.93 & 8.67436 & 3.49478 & 0.0303635 \\
\hline 1,250 & $-71.14 \pm 62.58$ & 0.024 & -0.6 & -1.04 & 1.00 & 15.92439 & 20.05058 & 0.0598588 \\
\hline \multicolumn{9}{|c|}{ Sample MW-98-13 } \\
\hline 550 & $70.21 \pm 30.06$ & 0.210 & 2.0 & 0.70 & 0.04 & 5.13239 & 2.33409 & 0.0176834 \\
\hline 625 & $43.53 \pm 12.63$ & 0.220 & 2.5 & 1.20 & 0.16 & 2.52784 & 2.22037 & 0.0089669 \\
\hline 700 & $93.31 \pm 8.94$ & 0.248 & 7.4 & 4.02 & 0.35 & 1.81667 & 1.97281 & 0.0062500 \\
\hline 750 & $73.86 \pm 8.77$ & 0.305 & 6.4 & 2.98 & 0.52 & 1.64990 & 1.60400 & 0.0056754 \\
\hline 800 & $71.25 \pm 10.29$ & 0.315 & 5.7 & 2.28 & 0.66 & 1.81008 & 1.55535 & 0.0062160 \\
\hline 850 & $87.57 \pm 12.12$ & 0.269 & 5.1 & 2.45 & 0.78 & 2.44351 & 1.81587 & 0.0083540 \\
\hline 925 & $28.02 \pm 20.21$ & 0.271 & 0.7 & 0.54 & 0.86 & 5.61575 & 1.80578 & 0.0193740 \\
\hline 1,000 & $-25.73 \pm 34.34$ & 0.310 & -0.3 & -0.38 & 0.93 & 11.68488 & 1.58049 & 0.0401112 \\
\hline 1,075 & $58.66 \pm 52.11$ & 0.099 & 0.5 & 0.58 & 0.97 & 17.35762 & 4.93443 & 0.0598414 \\
\hline 1,150 & $245.43 \pm 133.90$ & 0.011 & 1.5 & 0.79 & 0.98 & 23.50962 & 43.98451 & 0.0907644 \\
\hline 1,250 & $276.14 \pm 93.99$ & 0.016 & 2.5 & 1.17 & 1.00 & 15.81460 & 29.40997 & 0.0604691 \\
\hline
\end{tabular}


Table 2. Geochronologic analyses of selected samples of Westdahl volcanic rocks-Continued.

\begin{tabular}{|c|c|c|c|c|c|c|c|c|}
\hline Step $\left({ }^{\circ} \mathrm{C}\right)$ & Age (k.y.) & $\mathrm{K} / \mathrm{Ca}$ ratio & $\begin{array}{c}\text { Radiogenic }{ }^{40} \mathrm{Ar} \\
\text { (pct) }\end{array}$ & $\begin{array}{c}\text { Radiogenic }{ }^{40} \mathrm{Ar} \\
\left(10^{-15} \mathrm{~mol}\right)\end{array}$ & $\Sigma^{39} \mathrm{Ar}$ & ${ }^{40} \mathrm{Ar} /{ }^{\beta 9} \mathrm{Ar}$ ratio & ${ }^{37} \mathrm{Ar} /{ }^{\beta 9} \mathrm{Ar}$ ratio & ${ }^{36} \mathrm{Ar} /{ }^{39} \mathrm{Ar}$ ratio \\
\hline \multicolumn{9}{|c|}{ Sample MW-98-19 } \\
\hline 550 & $92.34 \pm 32.24$ & 0.217 & 1.4 & 1.17 & 0.07 & 9.77555 & 2.24988 & 0.0332576 \\
\hline 625 & $162.11 \pm 19.43$ & 0.209 & 3.7 & 4.04 & 0.22 & 6.33663 & 2.34241 & 0.0213024 \\
\hline 700 & $100.25 \pm 13.66$ & 0.202 & 4.0 & 3.04 & 0.40 & 3.69174 & 2.42670 & 0.0126789 \\
\hline 750 & $62.38 \pm 12.07$ & 0.210 & 3.3 & 1.94 & 0.59 & 2.77661 & 2.32839 & 0.0097424 \\
\hline 800 & $70.21 \pm 15.96$ & 0.216 & 3.2 & 1.44 & 0.71 & 3.17341 & 2.26728 & 0.0110297 \\
\hline 850 & $50.09 \pm 23.93$ & 0.192 & 1.5 & 0.66 & 0.79 & 4.82689 & 2.54956 & 0.0168040 \\
\hline 900 & $33.91 \pm 41.50$ & 0.150 & 0.5 & 0.26 & 0.83 & 9.20915 & 3.26799 & 0.0319160 \\
\hline 975 & $-97.48 \pm 56.66$ & 0.127 & -0.8 & -0.71 & 0.88 & 17.40183 & 3.83294 & 0.0604461 \\
\hline 1,075 & $-148.45 \pm 109.84$ & 0.063 & -0.6 & -0.95 & 0.91 & 38.28517 & 7.77302 & 0.1324700 \\
\hline 1,175 & $104.64 \pm 95.63$ & 0.015 & 0.6 & 1.24 & 0.98 & 24.42616 & 32.48473 & 0.0912831 \\
\hline 1,250 & $-122.42 \pm 109.16$ & 0.033 & -1.5 & -0.32 & 1.00 & 11.86961 & 14.53682 & 0.0448507 \\
\hline \multicolumn{9}{|c|}{ Sample MW-98-20 } \\
\hline 550 & $61.19 \pm 35.35$ & 0.235 & 1.0 & 0.59 & 0.05 & 8.96216 & 2.08341 & 0.0306064 \\
\hline 625 & $109.56 \pm 18.09$ & 0.269 & 3.3 & 2.22 & 0.16 & 4.91298 & 1.81866 & 0.0165880 \\
\hline 700 & $98.38 \pm 11.63$ & 0.300 & 4.5 & 3.42 & 0.34 & 3.26659 & 1.62908 & 0.0110180 \\
\hline 750 & $108.52 \pm 11.32$ & 0.307 & 5.5 & 3.62 & 0.51 & 2.92874 & 1.59657 & 0.0098135 \\
\hline 800 & $109.41 \pm 14.21$ & 0.281 & 4.9 & 2.63 & 0.63 & 3.29322 & 1.74196 & 0.0110837 \\
\hline 875 & $110.68 \pm 16.48$ & 0.243 & 3.5 & 2.65 & 0.76 & 4.72533 & 2.01165 & 0.0160011 \\
\hline 950 & $43.08 \pm 24.37$ & 0.230 & 0.8 & 0.81 & 0.86 & 8.01694 & 2.13070 & 0.0275121 \\
\hline 1,050 & $39.50 \pm 38.35$ & 0.197 & 0.4 & 0.69 & 0.95 & 13.73278 & 2.48070 & 0.0469701 \\
\hline 1,125 & $5.22 \pm 137.67$ & 0.025 & 0.0 & 0.02 & 0.97 & 46.88631 & 19.55786 & 0.1641400 \\
\hline 1,250 & $84.44 \pm 123.17$ & 0.020 & 0.3 & 0.52 & 1.00 & 40.00493 & 24.59039 & 0.1418700 \\
\hline
\end{tabular}


Table 2. Geochronologic analyses of selected samples of Westdahl volcanic rocks-Continued.

\begin{tabular}{|c|c|c|c|c|c|c|c|c|}
\hline Step $\left({ }^{\circ} \mathrm{C}\right)$ & Age (k.y.) & $\mathrm{K} / \mathrm{Ca}$ ratio & $\begin{array}{c}\text { Radiogenic }{ }^{40} \mathrm{Ar} \\
\text { (pct) }\end{array}$ & $\begin{array}{c}\text { Radiogenic }{ }^{40} \mathrm{Ar} \\
\left(10^{-15} \mathrm{~mol}\right)\end{array}$ & E39Ar & ${ }^{40} \mathrm{Ar} /{ }^{39} \mathrm{Ar}$ ratio & ${ }^{37} \mathrm{Ar} /{ }^{39} \mathrm{Ar}$ ratio & ${ }^{36} \mathrm{Ar} /{ }^{39} \mathrm{Ar}$ ratio \\
\hline \multicolumn{9}{|c|}{ Sample MW-99-11 } \\
\hline 550 & $109.04 \pm 78.05$ & 0.400 & 2.5 & 0.38 & 0.01 & 13.40052 & 1.22376 & 0.0445540 \\
\hline 625 & $146.53 \pm 11.35$ & 0.557 & 10.1 & 3.86 & 0.08 & 4.47550 & 0.87872 & 0.0138636 \\
\hline 700 & $136.54 \pm 6.37$ & 0.685 & 17.0 & 6.48 & 0.22 & 2.47385 & 0.71504 & 0.0071478 \\
\hline 775 & $128.72 \pm 3.60$ & 0.719 & 22.7 & 12.50 & 0.49 & 1.74780 & 0.68103 & 0.0047614 \\
\hline 850 & $119.55 \pm 3.50$ & 0.682 & 21.8 & 12.20 & 0.78 & 1.69284 & 0.71790 & 0.0046834 \\
\hline 925 & $135.05 \pm 7.56$ & 0.467 & 18.4 & 5.15 & 0.89 & 2.26757 & 1.04835 & 0.0065591 \\
\hline 975 & $119.70 \pm 17.80$ & 0.250 & 9.4 & 1.86 & 0.93 & 3.90890 & 1.95398 & 0.0125287 \\
\hline 1,075 & $88.39 \pm 24.54$ & 0.092 & 1.9 & 1.35 & 0.97 & 14.27498 & 5.30098 & 0.0488752 \\
\hline 1,175 & $374.37 \pm 50.26$ & 0.033 & 4.8 & 2.49 & 0.99 & 23.74274 & 14.71416 & 0.0806108 \\
\hline 1,275 & $533.20 \pm 109.16$ & 0.032 & 11.4 & 1.32 & 1.00 & 14.24975 & 15.14290 & 0.0469688 \\
\hline \multicolumn{9}{|c|}{ Sample MW-99-22 } \\
\hline 550 & $38.61 \pm 55.89$ & 0.157 & 1.0 & 0.19 & 0.03 & 6.13437 & 3.12069 & 0.0214344 \\
\hline 625 & $91.00 \pm 18.80$ & 0.181 & 5.1 & 1.43 & 0.12 & 2.74090 & 2.70104 & 0.0095604 \\
\hline 700 & $99.72 \pm 10.57$ & 0.209 & 9.0 & 3.10 & 0.29 & 1.69930 & 2.33659 & 0.0058869 \\
\hline 750 & $98.61 \pm 10.96$ & 0.232 & 10.9 & 2.77 & 0.45 & 1.39856 & 2.11091 & 0.0048116 \\
\hline 825 & $96.15 \pm 8.72$ & 0.232 & 10.1 & 3.83 & 0.68 & 1.46213 & 2.10572 & 0.0050379 \\
\hline 900 & $72.52 \pm 11.12$ & 0.187 & 6.0 & 2.20 & 0.85 & 1.87514 & 2.61529 & 0.0067018 \\
\hline 1,000 & $46.51 \pm 20.62$ & 0.125 & 1.9 & 0.73 & 0.93 & 3.79769 & 3.89473 & 0.0137031 \\
\hline 1,100 & $-7.13 \pm 49.22$ & 0.078 & -0.1 & -0.06 & 0.98 & 14.27109 & 6.23847 & 0.0500846 \\
\hline 1,250 & $-42.91 \pm 130.82$ & 0.010 & -0.2 & -0.17 & 1.00 & 30.69126 & 46.41779 & 0.1171200 \\
\hline
\end{tabular}


Table 2. Geochronologic analyses of selected samples of Westdahl volcanic rocks-Continued.

Sample MW-00-4

\begin{tabular}{|c|c|c|c|c|c|c|c|c|}
\hline 550 & $-29.89 \pm 115.66$ & 0.145 & -0.2 & -0.08 & 0.02 & 44.21059 & 3.38133 & 0.1508800 \\
\hline 625 & $49.12 \pm 35.89$ & 0.178 & 0.6 & 0.67 & 0.10 & 26.50934 & 2.75064 & 0.0899593 \\
\hline 700 & $112.02 \pm 20.89$ & 0.206 & 2.2 & 3.32 & 0.27 & 16.10772 & 2.37362 & 0.0539813 \\
\hline 775 & $126.26 \pm 12.86$ & 0.239 & 4.2 & 4.90 & 0.50 & 9.54845 & 2.04664 & 0.0315429 \\
\hline 850 & $118.51 \pm 12.81$ & 0.230 & 4.2 & 4.03 & 0.70 & 8.86470 & 2.13133 & 0.0293352 \\
\hline 925 & $-3.94 \pm 22.71$ & 0.218 & -0.1 & -0.08 & 0.83 & 16.71394 & 2.24218 & 0.0572333 \\
\hline 1,000 & $91.23 \pm 39.93$ & 0.182 & 0.9 & 1.25 & 0.91 & 30.79472 & 2.69121 & 0.1040000 \\
\hline 1,100 & $157.71 \pm 53.55$ & 0.058 & 1.3 & 1.46 & 0.96 & 39.27282 & 8.40812 & 0.1335900 \\
\hline 1,250 & $242.97 \pm 78.46$ & 0.023 & 1.4 & 1.51 & 1.00 & 54.86491 & 21.07853 & 0.1890300 \\
\hline
\end{tabular}


Table 2. Geochronologic analyses of selected samples of Westdahl volcanic rocks-Continued.

\begin{tabular}{|c|c|c|c|c|c|c|c|c|}
\hline Step $\left({ }^{\circ} \mathrm{C}\right)$ & Age (k.y.) & K/Ca ratio & $\begin{array}{c}\text { Radiogenic }{ }^{40} \mathrm{Ar} \\
\text { (pct) }\end{array}$ & $\begin{array}{c}\text { Radiogenic }{ }^{40} \mathrm{Ar} \\
\left(10^{-15} \mathrm{~mol}\right)\end{array}$ & $\Sigma^{39} \mathrm{Ar}$ & ${ }^{40} \mathrm{Ar} /{ }^{39} \mathrm{Ar}$ ratio & ${ }^{37} \mathrm{Ar} /{ }^{39} \mathrm{Ar}$ ratio & ${ }^{36} \mathrm{Ar} /{ }^{39} \mathrm{Ar}$ ratio \\
\hline \multicolumn{9}{|c|}{ Sample MW-00-28 } \\
\hline 550 & $-675.01 \pm 113.00$ & 0.226 & -7.9 & -1.65 & 0.01 & 25.83424 & 2.16320 & 0.0949179 \\
\hline 625 & $-16.64 \pm 20.09$ & 0.317 & -0.4 & -0.30 & 0.09 & 11.35275 & 1.54331 & 0.0390215 \\
\hline 700 & $27.06 \pm 12.58$ & 0.336 & 1.2 & 0.76 & 0.20 & 6.75593 & 1.45504 & 0.0229927 \\
\hline 775 & $40.25 \pm 8.26$ & 0.277 & 2.4 & 2.04 & 0.41 & 5.10456 & 1.76775 & 0.0173575 \\
\hline 850 & $32.12 \pm 8.40$ & 0.260 & 1.9 & 1.56 & 0.62 & 5.04698 & 1.87871 & 0.0172773 \\
\hline 925 & $16.84 \pm 11.52$ & 0.238 & 0.7 & 0.61 & 0.77 & 7.23872 & 2.05816 & 0.0249018 \\
\hline 1,000 & $-22.66 \pm 21.62$ & 0.187 & -0.4 & -0.53 & 0.87 & 15.34630 & 2.61887 & 0.0529003 \\
\hline 1,075 & $48.00 \pm 34.86$ & 0.096 & 0.6 & 0.62 & 0.92 & 23.30131 & 5.06194 & 0.0797848 \\
\hline 1,150 & $251.17 \pm 46.36$ & 0.028 & 2.5 & 2.65 & 0.96 & 29.75259 & 17.19841 & 0.1029800 \\
\hline 1,250 & $291.20 \pm 53.39$ & 0.037 & 2.5 & 2.51 & 1.00 & 35.27713 & 13.06215 & 0.1201000 \\
\hline
\end{tabular}

\begin{tabular}{|c|c|c|c|c|c|c|c|c|}
\hline \multicolumn{9}{|c|}{ Sample MW-00-65 } \\
\hline 550 & $1.70 \pm 0.14$ & 0.162 & 29.2 & 3.18 & 0.01 & 8.11630 & 3.02449 & 0.0203042 \\
\hline 625 & $1.80 \pm 2.61 \mathrm{e}-2$ & 0.201 & 45.9 & 21.30 & 0.08 & 5.47284 & 2.43156 & 0.0106945 \\
\hline 700 & $1.83 \pm 1.11 \mathrm{e}-2$ & 0.254 & 70.8 & 72.30 & 0.31 & 3.60671 & 1.92962 & 0.0041027 \\
\hline 775 & $1.67 \pm 9.58 \mathrm{e}-3$ & 0.270 & 72.3 & 87.00 & 0.62 & 3.22204 & 1.81240 & 0.0035285 \\
\hline 850 & $1.63 \pm 1.30 \mathrm{e}-2$ & 0.227 & 60.5 & 48.60 & 0.79 & 3.76438 & 2.15789 & 0.0056398 \\
\hline 925 & $1.65 \pm 2.42 \mathrm{e}-2$ & 0.154 & 37.0 & 23.90 & 0.88 & 6.21708 & 3.16555 & 0.0141347 \\
\hline 1,000 & $1.58 \pm 3.65 \mathrm{e}-2$ & 0.126 & 31.4 & 13.30 & 0.93 & 7.02265 & 3.87774 & 0.0173891 \\
\hline 1,100 & $1.63 \pm 6.04 \mathrm{e}-2$ & 0.063 & 14.5 & 9.88 & 0.96 & 15.66218 & 7.76967 & 0.0475115 \\
\hline 1,250 & $1.73 \pm 0.13$ & 0.015 & 5.9 & 10.50 & 1.00 & 39.73670 & 31.33654 & 0.1353000 \\
\hline
\end{tabular}




\begin{tabular}{|c|c|c|c|c|c|c|c|c|}
\hline Step $\left({ }^{\circ} \mathrm{C}\right)$ & Age (k.y.) & $\mathrm{K} / \mathrm{Ca}$ ratio & $\begin{array}{l}\text { Radiogenic }{ }^{40} \mathrm{Ar} \\
\text { (pct) }\end{array}$ & $\begin{array}{c}\text { Radiogenic }{ }^{40} \mathrm{Ar} \\
\left(10^{-15} \mathrm{~mol}\right)\end{array}$ & $\Sigma^{39} \mathrm{Ar}$ & ${ }^{40} \mathrm{Ar} /{ }^{39} \mathrm{Ar}$ ratio & ${ }^{37} \mathrm{Ar} /{ }^{39} \mathrm{Ar}$ ratio & ${ }^{36} \mathrm{Ar} /{ }^{39} \mathrm{Ar}$ ratio \\
\hline \multicolumn{9}{|c|}{ Sample MW-00-71 } \\
\hline 550 & $40.40 \pm 38.97$ & 0.603 & 0.6 & 0.35 & 0.03 & 20.30067 & 0.81268 & 0.0685212 \\
\hline 625 & $107.10 \pm 17.23$ & 0.673 & 3.2 & 2.28 & 0.09 & 9.91240 & 0.72746 & 0.0326728 \\
\hline 700 & $85.12 \pm 6.95$ & 0.682 & 5.6 & 5.42 & 0.28 & 4.53004 & 0.71829 & 0.0146791 \\
\hline 750 & $59.25 \pm 6.65$ & 0.604 & 5.1 & 3.13 & 0.44 & 3.43339 & 0.81033 & 0.0112523 \\
\hline 800 & $68.64 \pm 6.31$ & 0.526 & 6.1 & 4.74 & 0.65 & 3.33302 & 0.93106 & 0.0108484 \\
\hline 850 & $63.20 \pm 8.15$ & 0.421 & 4.1 & 3.48 & 0.81 & 4.55257 & 1.16168 & 0.0150971 \\
\hline 900 & $36.97 \pm 18.98$ & 0.308 & 1.2 & 0.77 & 0.87 & 9.13284 & 1.58800 & 0.0309825 \\
\hline 950 & $202.43 \pm 34.90$ & 0.252 & 3.2 & 2.45 & 0.91 & 19.00873 & 1.94283 & 0.0628458 \\
\hline 1,000 & $33.24 \pm 54.94$ & 0.244 & 0.3 & 0.29 & 0.94 & 33.58555 & 2.00465 & 0.1138900 \\
\hline 1,050 & $136.24 \pm 80.50$ & 0.217 & 0.7 & 1.28 & 0.96 & 58.47571 & 2.25490 & 0.1971600 \\
\hline 1,100 & $525.82 \pm 119.85$ & 0.150 & 1.8 & 3.72 & 0.99 & 87.51622 & 3.26453 & 0.2918200 \\
\hline 1,250 & $19.45 \pm 202.80$ & 0.058 & 0.0 & 0.09 & 1.00 & 146.02550 & 8.33079 & 0.4963100 \\
\hline \multicolumn{9}{|c|}{ Sample MW-00-77 } \\
\hline 550 & $91.82 \pm 30.16$ & 0.221 & 3.0 & 0.88 & 0.05 & 4.90783 & 2.20943 & 0.0167299 \\
\hline 625 & $91.23 \pm 9.54$ & 0.257 & 6.1 & 3.55 & 0.24 & 2.39200 & 1.90634 & 0.0081344 \\
\hline 700 & $106.06 \pm 7.78$ & 0.241 & 9.7 & 5.32 & 0.49 & 1.74990 & 2.02837 & 0.0059163 \\
\hline 750 & $101.81 \pm 9.64$ & 0.232 & 9.0 & 3.55 & 0.67 & 1.82263 & 2.11274 & 0.0062081 \\
\hline 825 & $98.38 \pm 11.96$ & 0.191 & 5.9 & 2.85 & 0.81 & 2.65744 & 2.56314 & 0.0091795 \\
\hline 900 & $83.33 \pm 20.63$ & 0.187 & 3.0 & 1.28 & 0.89 & 4.51056 & 2.60950 & 0.0155442 \\
\hline 1,000 & $81.09 \pm 23.64$ & 0.212 & 2.1 & 1.17 & 0.96 & 6.31295 & 2.30924 & 0.0215710 \\
\hline 1,100 & $141.01 \pm 76.86$ & 0.034 & 1.0 & 0.69 & 0.99 & 21.52840 & 14.34388 & 0.0761243 \\
\hline 1,250 & $127.08 \pm 164.44$ & 0.008 & 0.5 & 0.36 & 1.00 & 35.56935 & 60.15612 & 0.1366100 \\
\hline
\end{tabular}

